\title{
Past Is Not a Frozen Concept: Considerations about Heritage Conservation in a Fast Changing World
}

\author{
Paolo Ceccarelli \\ Department of Architecture, University of Ferrara, Ferrara, Italy \\ Email:cec@unife.it
}

\begin{abstract}
The paper introduces seven essays from China, Europe, India, Japan, South Africa and South America included in issue No. 3 of Built Heritage. It focuses on the necessity of a critical review of Western principles and methods of heritage conservation and suggests an approach open to different cultural models and practices. Concepts of history, memory, authenticity are analysed and some new issues originated by massive migrations and urbanisation processes examined. Heritage conservation is seen as an opportunity for developing post-Western/nonWestern theoretical models, methodologies and practices.
\end{abstract}

KEYWORDS conservation, memory, authenticity, cross-fertilisation, collective action, de-colonisation, postWestern/non-Western

This special issue of Built Heritage 'Global and Local Challenges in Non-Western Heritage Conservation' aims at exploring theories, methods and experiences on which are based approaches to history, heritage, memory, conservation in Non-Western cultures and societies.

There is a widely shared opinion that many theoretical and methodological principles developed over the past decades by Western culture (and applied all over the world) should be reconsidered. And there is also an increasing awareness that alternative ideas and practices developed by other cultures can possibly deal with and give better answers to present and future problems.

These positions are the consequence of substantial changes that have taken and are taking place at world scale. Changes that have a strong impact on urban systems and their planning, on landscapes, on architectural design, and on the protection of heritage and its conservation.

For many years, studies in different disciplines have highlighted the crisis of theoretical models and operational tools generated by Western culture and spread throughout the world during the last two centuries. These critical reflections, developed by many well-known scholars (Chakrabarty 2000; Rüsen 2007; Said 1978, 1988; Wallerstein 2006; Winter 2012), correspond to an equally important literature about the need to take into careful consideration the variety of cognitive models different cultures follow (Comaroff 2012; Connell 2007; Fabian 2014; Jullien 2015; Kilani 1994;) Many countries of the world have given diversified interpretations to common similar issues, and dealt with and solved similar problems in different ways. Although one recognises the relevance of Western interpretative models and the impact their diffusion has had, on the other hand, it should be acknowledged that they had to be adjusted to local conditions; and above all that it is appropriate (and necessary) to take into account the contributions each culture gives.

In recent years the awareness of the limits of the Western models has been accentuated by their growing difficulties in dealing with, and managing new unexpected problems, which are not occasional and of slight relevance, but anticipate more general trends in global society. At the beginning of a new millennium, the world had undergone transformations, contradictions, conflicts as it had not been for many decades since the years when a new order came about at the end of the Second World War, the end of colonialism, the emergence of socialist countries. Western leadership is in a growing crisis. Europe is increasingly closed in itself and unable to propose new perspectives. 
An example for all is the inadequacy shown by European countries to manage current immigration flows from Asia, the Middle East and Africa. Faced with a series of new situations that do not correspond to the traditional patterns of European life and culture, answers have been contradictory, uncertain and inadequate. The idea of solving the problem by closing borders and building walls shows how unidirectional and selfish the relationship between Europe and the rest of the world has been. The same happens with the US, which founded their history and wealth on acceptance and inclusion and is now in favour of closing borders, building a wall to protect from Mexico, and to expel foreigners living and working there for many years. Both the Old and the New Continent seem to have lost the sense of how today's world is and the meaning of their role.

Against these positions of cultural dominance and closure, it must be emphasised that interchange between cultures has always existed and has always been fruitful. There is no need to remember the impact that several thousand years ago the Egyptian culture had on the Achaemenid architecture and city planning in West Asia, the influence exerted on the ancient Greek civilisation and art by Phoenicians and Egyptians (Bernal 1987), the complex cross-cultural blend of the Gandāhra art (Nehru 1989; Pingree 1978), and the crucial and fruitful influence of Chinese culture on Japan.

However, despite all the declarations in favour of the importance of cross-cultural fertilisation and the necessity to protect and promote diversity when dealing with social and economic problems in different regions of the world (in order to be in harmony with local conditions), the practices of the leading international agencies, and the rules on which their interventions are based are still heavily dependent on Western paradigms. In spite of the fact that the way a phenomenon is defined, and a particular significance is given to its change over time, definitions given at a specific moment of this process tend to be considered immutable, objective, valid for everyone, everywhere. It follows that differences from a specific principle, naturally due to the flow of time or to the ways different cultures see it, are interpreted as marginal variations. They are seen as limited deviations from the standard. They can be accepted in the name of cultural diversity, without lessening the orthodox interpretation.

In official documents and declarations concerning the protection and conservation of heritage, it is never clearly said that the agreed definitions are purely conventional (but not less important and binding because of this) and may change over time and according to the cultures using them. Some of these problems will be examined in the following pages.

Articles published in this issue express the processes of reflection and elaboration (both theoretical and through concrete experiences) of heritage conservation, in progress in China, Japan, India, Latin America (specifically from Chile) and South Africa. Professor Qing Chang examines contemporary changes of Shanghai's historic areas as an example of the Chinese approach to conservation; Professor A. G. Krishna Menon reviews current concepts of urban planning in India and suggests new directions for work. Japanese contributions focus on the development of a postWestern/non-Western movement in architecture and planning (Professor Hidenobu Jinnai's paper), and the Machizukuri practice, as an alternative way of approaching urban and environmental issues (Professor Takashi Ariga's paper); Professor Fernando Perez analyses experiences of heritage transformation and adaptation in Chile. The paper by Professor Tomà Berlanda explores instead from a South African perspective the necessity of substantial changes in the education process in architectural conservation, which is still heavily influenced by Western models. Finally, Professor Giulio Verdini thoroughly examines changes in conservation strategies that will be originated by transformations of cities and landscapes produced by global urbanisation.

I think that reading them will stimulate the development of new original arguments and suggest the opportunity of organising them in structured systems instead of leaving them as fragmented observations and individual experiences.

The post-Western/non-Western project (Ceccarelli 2016) launched last year to explore these issues at a worldwide dimension has found a point of contact with the philosophy of Built Heritage which lies on the fundamental differences regarding built heritage conservation between China and the West, recognising these differences as a source of creativity'. It has also suggested collecting the first set of contributions on these issues from authors belonging to different cultural regions of the world. This third special issue of Built Heritage 'Global and Local Challenges in Non-Western Heritage Conservation' is an initial contribution to promote a wider discussion. It obviously has limits and gaps as in all experiments: an unavoidable condition when new territories are explored.

\section{The Context}

We can list a number of key issues to be taken into consideration to better understand and contextualise global trends that will influence cultural models in the next future, specific problems they will pose to the conservation of heritage, and how they will be answered. They are: 
- The gradual shift of the geographical centre of gravity of world power. The poles of reference will transfer to the East, and the South of the planet will emerge. As a consequence, cultural models and value systems that for a long time were considered marginal will become central.

- The new planetary conditions of the human settlement. Since in the future most of the world population will live in urban areas, the traditional ideas of the city, of its physical structure, its role, and the way it works will change. As a consequence, the system of meanings and values upon which cities were based will also change.

- The increasing fragmentation, stratification of social structures producing urban culture, and the increasing speed of their change. The coexistence and overlay of different cultures; their interaction and mutual influence; their conflicts. These new conditions will produce substantial changes in cultural paradigms and models.

- The issue of tangible heritage conservation that was so central to the making of political identities of Western societies (and later spread in the whole world, through the action of international agencies and the diffusion of tourism) will also change. History, memory, heritage authenticity and the very idea of conservation, just to mention some principles, are differently interpreted by different societies and their multiple components. These interpretations also change over the years. This will strongly differentiate how heritage is taken care of in different regions of the world. It will also make it necessary to find solutions that facilitate the coexistence of different heritage conservation approaches and management solutions surely a positive and enriching advancement compared to the 'single thought' of conservation still in use.

- Digital technological innovations and the development of artificial intelligence will have a dramatic impact on the way people relate to the real world. They will make it possible to create a virtual reality more 'real' than the original one. How these developments affect the way heritage is perceived, conserved, reproduced, and also enhanced through 'augmented reality' must be taken into serious consideration.

\section{Past Is Not a Frozen Concept}

A first issue I wish to address is that the past is not a frozen concept. The criteria by which we analyse and define what was made in the past and still surrounds us are not the same for every society. And in each society they are not immutable over time. These criteria are conventional and functional to the way each society works. This is true both for basic principles of human society and for minor elements. This fact is generally underestimated and often ignored in spite if its evidence.

To be clearer on this issue, let me refer to an interesting, even if extreme, case. Pukapuka is a small atoll of the Cook Islands, well-known among anthropologists because its inhabitants are used to invent past events when this helps to solve present problems successfully. In the 1980s a form of social organisation called Akatawa was introduced in order to make local governance more efficient. The decision was based on the assumption that it was a traditional institution, an important component of local history. This story was not true, but most people endorsed the choice on the assumption that they had previously experienced the positive role of Akatawa in the life of the community. Pukapukans are used to invent history and tradition when this is useful to support and legitimate new choices (Borofsky 1987). They surely have a different and more flexible (a possibly interesting) idea of history than the one codified by Academia and international organisations. But they are not the only case. As Eric Hobsbawm and Pierre Nora have shown to us in their books, in the $19^{\text {th }}$ century both Great Britain and France invented historic events and traditions to reinforce the legitimacy of their national institutions (Hobsbawm 1983; Ministère de la Culture 1997, 1998; Nora 1992; Poulot 2006; Revel and Hunt 1995).

The ideas of past and heritage we had a century ago are fundamentally different from the ones we have today, and there are already signs that they will further change in the future. As Walter Benjamin said in his seminal essay The Work of Art in the Age of Mechanical Reproduction (Benjamin 1935): 'During long periods of history, the mode of human sense perception changes with humanity's entire mode of existence. The manner in which human sense perception is organised, the medium in which is accomplished, is determined not only by nature but by historical circumstances as well.' This is true for all cultures in the world and is absolutely visible in Western culture. In our case, it applies to the concept of history and the relationship between past, present and future, and consequently to the ideas of memory, authenticity and uniqueness, conservation and integrity, and so on. However, we should not forget that, as Karl Marx said: 'Men make their own history, but they do not make it just as they please, they do not make under circumstances chosen by themselves, but under circumstances directly encountered, given and transmitted from the past.' (Morris 2000, 15)

The dominant influence of Western culture has made 
of its own principles a general rule, admitting, however, the possibility of different positions. This attitude is often more a forced concession than the acknowledgement that the principles of heritage conservation are bound to culture and time. And that a culture of conservation, corresponding to new conditions of human society, is still in the process of being formulated.

One of the problems that have always troubled human societies is how to effectively save the memory of the past through the conservation either of tangible or intangible elements or, of both. The memory of the past is common to almost all societies and cultures, yet it is also one of the elements that rely on different elements, plays different roles and takes different forms (Augé 2003; Le Goff 1992; Lowenthal 1985; Olivier 2008; Todorov 2004). Western civilisation is probably the one giving physical, tangible elements, a crucial role in conserving the memory of an event. Memory as history has always been a field of invention. Depending on the intentions of a particular moment, or of political, cultural or religious necessities it is used to legitimate an event or to give value to a physical element.

Obviously different societies do not have the same approach to this issue. Although intangible, abstract and mythical elements are mostly used to remember fundamental historical moments, there is a constant search for confirmations in things that you can still see, touch and experiment physically.

Western societies privilege physical aspects while others often prefer the safeguard of intangible elements. In addition, the ways of conserving what we inherit from the past are not defined once and for all in a precise and final form; both forms and contents of this process change over the course of time.

Memory expressed in physical, tangible terms has always been a key element of political legitimacy, of intellectual primacy, of economic power in each Western country and later this model has been exported to colonies and countries economically dominated. It is from the $19^{\text {th }}$ century that the preservation of physical memories (places and monuments) has also become a tool for either reinforcing or creating a national identity to be used inside each country but also as an expression of power in colonial policies (Edwards 2003; Hamilakis 2003; Joyce 2003; Kane 2003; Revel, Levi 2002). It is the case of the 'political' or 'public' use of history. However, it should not be forgotten that the very concept of memory used by Western culture in the 19th and 20th centuries has progressively changed (especially as a result of Freud's work [Freud 1985]). Contemporary Western culture, which heavily depends on the media, projects an image of individual and collective memory that is more complex than the one defined by Maurice Halbwachs in the 1920s (Halbwachs 1950). And then, there is the limitless retrieval capacity of digital technology.

Over time, the conservation of memory has had different declinations with a strong accentuation of symbolic aspects, frequently of a religious nature. Think of the care with which specific architectural elements such as castles, temples, palaces or historic districts, streets and squares, or in alternative landscapes (Wu 2012) are preserved everywhere because of ancient events and legends associated with them.

As a consequence memory has therefore been subject to actions aimed at implementing these functions, including the creation of technical and administrative structures able to guarantee the maintenance and restoration of physical properties. However, the concept of national identity has progressively changed, and also the elements on which it is based have changed. The past and its preservation have become relatively important compared to other tools and variables meant to defend local identity.

As an alternative, a new important use of memory and heritage, both physical and immaterial, has developed: it is linked to the cultural and tourist use of heritage. Historic cities, monuments, cultural landscapes become economic resources of great importance to the market. This originates an inevitable commodification process. They lost an ideological role to become goods to be consumed. Heritage properties must be better preserved to meet the tourist demand, and at the same time, their supply must be increased to provide new 'fresh' cultural goods to be enjoyed by visitors. This explains the surge of interest to be included in the UNESCO World Heritage List and the continuous search for sometimes unlikely world heritages.

Depending on the interpretations given to the role of memory and the purposes that are attributed to its preservation, conservation inevitably becomes a continuous process of changes and adjustments. It is a process that safeguards some aspects and modifies others, adds and subtracts elements, and above all attributes over time different meanings and roles to the tangible and intangible items. Solutions that a century ago were considered correct now seem instead wrong, and in the next future the same will happen to our present principles and formulas. In addition we must be aware of the fact that cultural models of new generations will be substantially different from the present ones, and that they are in a process of continuous change, at a speed never experienced before. Principles 
that were meaningful to fathers are insignificant to their children, who replace them with other value systems.

This is why the conservation of memory is an important key to analyse cultural diversities, and how cultures interact, reciprocally contaminate, and can also be conflicting. Besides it also represents the way how every society mirrors and positions itself towards the future. It is indeed an important element to study and understand the present juncture of social, economic and political processes of change in the societies in which we live. As Henri-Pierrev Jeudy says 'Conservation strategies are characterised by a process of reflexivity that gives them meaning and purpose. The concept of cultural heritage draws its present meaning from a museographical doubling of the world. To have a recognised manageable cultural heritage a society must mirror itself. It must use its places, objects, monuments as intelligible reflections of its history, and its culture. Society must make a spectacular doubling that makes possible to use its objects and territory as a permanent opportunity of speculation about the future.' (Jeudy 2008)

What we have seen suggests the opportunity of carrying on further research on the possibility that different positions about the meaning of history and its role, and the reconstruction of past events through memory coexist. It is also important to increase the awareness that theories and methods of preserving the past change in time.

\section{Conservation as a Project}

As history and memory are conventions, conservation is a project. Conservation is not an established doctrine; it is a project, an intention. As a consequence, it changes in time and in accordance with changing cultural contexts. It can be centred on the physical aspect of a property, but on the opposite, it can overlook its tangible dimension in favour of conserving its ideal significance or the symbolic relevance of an event related to it.

Possibly the most serious inadequacy of the present theory of conservation (the one to which the international culture refers to) is to be unaware that the principles on which it relies are relative and dated. They are in fact expressions of a moment that went past. An appropriate theory should address situations that are continuously changing, and anticipate the new problems that this will generate.

This situation originates a number of problems that should be taken into careful account. A couple of them are particularly important. They are: first, how the conservation process is related to the future and not only to the past, and second, how the conservation of the existing heritage, and the one produced by the present culture, can be implemented in urban contexts that will radically change.

I quote Paolo Jedlowsky, a scholar who has thoroughly explored theories of memory in Western culture: 'What we call memories are representations of things that happened in the past. In a more or less symmetrical way, we can imagine what will happen in the future. But what happens when we remember which future we had imagined in the past? ... What the past meant not only as a "no more", but as a "not yet" suggests that in some cases the memory of what was imagined in the past is a reservoir of possibilities.' (Jedlowski 2017, 9)

Cities and the architectures that represent the near past and are our present heritage, when they were built were in fact conceived as representations of the future: that is, our present. The same will happen when we create new urban developments and new buildings; one must be aware of the fact that in the future they will become heritage, and be conserved as such. But why and in which way will they be preserved?

It is interesting to see that similar approaches are followed by archaeologists: 'Future archaeological questions could be directed toward the ways in which meanings and identities are attributed and negotiated, rather than in the direction of origins. Yet... there are often disjunctures between these imaginary landscapes... Together they form a mosaic of possible histories and a corresponding mélange of present and potential futures.' (Meskell 1999)

Societies that evolved linearly in time, without contradictions, within well-defined and reasonable dimensions, and with their parts in a balanced and hierarchical relationship could imagine built environments, architectures and landscapes that would not change much in the future. For example, Europeans continue to think that since their buildings can last for a long time, they must be constructed to be easily maintained and preserved through wellestablished traditional methods, techniques and tools. But what happens when processes of urbanisation are very rapid, gigantic and inevitably messy?

In his paper on Shanghai, Qing Chang raises acutely the issues that large-scale and very rapid developments in early modern Chinese cities under the background of Western influences are posing for their conservation of their historic areas and artefacts. Modern housing estates, business buildings, and road infrastructure embody the image of a future that is worth to be preserved. But to adequately preserve the huge urban built heritage in these years is a difficult if not impossible task. The new built environment over the past 20 to 30 years with a large number of housing estates and business spaces scattered around and partly inserted into historic areas, 12 pieces 
of that in Shanghai for example, which has made the city almost in a mega-complex. Standards and building types change very fast, and to adjust existing buildings to new needs and regulations is often an extremely hard job. What to do then? What to select for conservation?

To make the conservation of future heritage viable, we cannot disregard the issue of how the present will be kept in the future. This will also enable us to better understand what to do with we have inherited from the past. The conservation experiences of Shanghai examined in Chang's paper are interesting but still a bit too in line with the Western approach to conservation because of the objective artefacts analogical to the West in early modern times of Shanghai. So, it's difficult for them to anticipate alternative and more original solutions, as they could have possibly done.

A second important suggestion for our future work can be drawn. Conservation does not concern only the past; it should also take into consideration the future, the 'not yet'. This implies a much stronger commitment to anticipate future scenarios and to understand what can and should be done now.

\section{A Multifaceted Authenticity}

Another area of discussion and elaboration of new ideas concerns the concept of 'authenticity' and its interpretation in different cultures and over time. (Lowenthal 2008; Potter 2010; Stovel 2007; Watertown, Watson 2011,2015) The impact that the mechanical reproduction of an original work of art by means of photographs and films would have produced on the concepts of authenticity and integrity was also clearly anticipated by Walter Benjamin. The opportunity to enjoy the image of an attractive landscape while sitting in your room changes the very nature of that landscape gives a different value to its components. In addition it enables thousands of people to experience something that is totally out of their reach. The reproduction becomes for them the reality.

20 years ago, in his world-famous bestseller Timeline, Michael Crichton argued that exasperated by a pervasive artificial environment, people look for 'authentic' evidences from the past. He wrote: 'The past is unarguably authentic. The past is a world that already existed... The past is real. It's authentic. And this will make the past unbelievably attractive. People... want to visit no other places, but other times... medieval walled cities, Buddhist temples, Mayan pyramids, Egyptian necropolises... the vanished world. And they don't want it to be fake. They don't want it to be made pretty, or cleaned up. They want it to be authentic.' (Crichton 1999) Unfortunately, things have today become more complex. In the issue No. 2 of Built Heritage, the paper by Alexandra Harrer 'The Legacy of Alois Riegl: Material Authenticity of the Monument in the Digital Age' develops interesting arguments on this matter. Digital technology has aggravated the mechanical reproduction effects Benjamin examined almost a century ago. The concept of authenticity in a world that builds reality in virtual terms is loosely related to an original artefact. Virtual reality and added reality inevitably modify the concept of authenticity since what one can see in reality has little to do with what is created virtually: this is much more attractive and convincing. The choice between what is illusory, but strongly realistic, and based on a glittering visual language on one side, and what remains from the past on the other is unfair. The interest in knowing what is real becomes marginal. The original is used to validate an imaginary added reality reconstruction.

This reintroduces an apparent paradox that has been previously considered. It is the fact that to correctly conserve the past we need to anticipate the future. And this may imply transformation.

How can we expect to establish correct rules for conserving heritage without taking into consideration the substantial changes that are taking place in the way people relate to reality and perceive it? And this future seems to be very different from the past.

The substitution of something real by a replica (which often is more attractive than the original model) or a fake has become popular in tourist areas but also in educational programs. Environments and monuments of symbolic values are reconstructed in order to enable visitors to have more satisfying experiences than the ones they would have in the real place. New technologies make further experiences possible. Destroyed architectures (or sites that are impossible to reach) are virtually reproduced in detail and integrated with lost decorations and paintings, furniture, objects. People wearing devices that become increasingly lighter and smaller can walk in them as the original inhabitants did, listen to sounds, smell odours...(Morey 2016). As we learn every day from the fake media news are often sadly assumed to be the real ones.

Another problem must be taken into consideration. There is an increasing risk that extremely attractive heritage properties and sites are endangered by their very success. It is the case of Macchu Picchu in Peru or Venice in Italy. The only way to save them is to sharply reduce the amount of visitors and offer alternative ways of experiencing them through new communication technologies or physical replicas. This means that for the largest share of 
people interested in knowing Macchu Picchu or Venice, the 'real' place is a fake one.

There are amazing examples of fake/authentic places in the Caribbean islands where invented small colonial towns have been built at tourist cruisers' mooring places. The towns become full of inhabitants and activities just before the cruisers arrive and close down as soon as they leave. The fake becomes as real and authentic as the prototype. Another well-known example is the historic site of Carcassonne in southern France. This UNESCO World Heritage Site was mostly invented by Viollet-le-Duc in $19^{\text {th }}$ century to create a false 'authentic and integer' medieval site; able to express in a very effective way the romance of ancient chivalry. The imagination of a medieval place is more relevant than the real place itself.

In Europe, there are famous cases of non-authentic urban environments that for different reasons have become authentic. They are historic sites or properties destroyed by war events that local people decided to rebuild 'as they were'.

The historic district and the Ghetto of Warsaw were rebuilt after destruction by Nazis in 1944. Old paintings and documents were used to reconstruct them 'as they were' in order to strongly state that an important part of Warsaw's history and culture survived its physical destruction. Playing such an important role in the Polish culture and society the new physical structures have become an authentic expression of the meaning and value of the Old Warsaw and its Ghetto.

Another similar case the Stari Most (old bridge) of Mostar, in Bosnia, that was destroyed in 1993, during the war between Croatia and Bosnia, because it witnessed and symbolised the possibility of peaceful and positive relationships between different cultures. The bridge was rebuilt exactly as it was because its real and authentic value was not embedded in some old stones but rather in the role it had performed. A couple of generations after their reconstruction both the historic district of Warsaw and the Mostar Bridge have fully become icons of authenticity.

The authentication statement drawn up at Nara (UNESCO 1994) focuses only on the material/physical. It is interesting to see how the idea of authenticity can be different, but equally true. A case that shows how fragile can be a rigid an abstract theory of authenticity is the unsuccessful experience of Oradour sur Glane in France (Olivier 2008). To more effectively preserve the memory of a Nazis' massacre in a peaceful village the French government decided to keep the place exactly as it was when its inhabitants had been slaughtered. It was assumed that the preservation of a totally authentic scenery would have had a much stronger and effective educational impact. This solution resulted wrong since it overlooked the inevitable alterations that time produces. After a few years the local doctor's car, which had been left as it was (still with a door open) when the driver was killed, had become a rusted junk that did not convey any message. The same had happened to buildings and open spaces. It was then necessary to create a new narrative of the event by electing some original elements only and organising a new discourse about that massacre (Olivier 2008).

Possibly the totally different approach followed for the Memorial of the Nanjing Massacre-based on a symbolic role of architectures and spaces-offers the possibility of reactions and memories that are more authentic and vivid than the 'authentic' ones in the French case.

Hidenobu Jinnai's considerations of the long and complex interplay between Japanese culture and Western culture, with their continuous reciprocal influences, suggest an important line of work, also advocated by A. G. K. Menon's paper. What emerges from the recent history of Japanese architecture and design is the relevance of reciprocal fertilisation in search of more appropriate answers to the needs of every society. Ideas of authenticity similiar to the ones of the traditional Japanese culture are often found in practices of profoundly different societies even if they are denied at a theoretical level. In his paper, Fernando Perez gives a good example of this and introduces a rather unorthodox approach to conservation. Since the $19^{\text {th }}$ century the Palace of La Moneda in Santiago is the home of the Chilean central government and expresses the continuity of civil power even through dramatic events. However, as Perez points out, '...the isolated building standing today between two modern public spaces is radically different, in shape and use, from the one originally erected. Thus, the process of change and adaptation suffered by La Moneda has allowed it to survive and keep its significant urban role'. Its transformation has been the solution for preserving the most important cultural value of the original architecture: to be a key symbol of Chilean democratic heritage.

In a word, authenticity is an important quality, but it is possibly more complex and elusive than the one suggested in official declarations, and before the 'Age of Virtual Reality'. The idea that authenticity is an objective value is very Western and is consistent with the idea that only the material aspect is relevant (Enders and Gutschow 1998). What is wrong in assuming that there are different ways of interpreting it? 


\section{Cultural Cross-Fertilisation}

At this point, it is worth to examine the crucial issue of the relationship and mutual contamination between cultures coming into contact with one another due to trade, colonialism, geographic discoveries, or even wars.

This complex and rich relationship in nuances implies, however, the need not only to analyse the most superficial appearances and elements. It is necessary to go deeper into many things. Differences and similarities are not only in form, but also in the way things are constructed, used, embedded in the contexts, and in their size also.

It is then interesting to begin to carefully think about what this means for the interpretation of memory, its preservation, and the concept of authenticity. This relationship, although it has some common elements, varies from one region to another, from one country to another and very often from one city or a countryside area to another.

This result is the consequence of the deep differences existing within great cultural systems. What Qing Chang, perspicaciously observes about the 'Chinese cosmopolitanism', which in Shanghai has special features, can be found in different forms in Indian or Japanese cities. However, it is something very different and cannot be reduced to the same model.

A. G. K. Menon develops a penetrating analysis of how some Western planning principles and methods have been either imposed or imported in India in the different moments of its recent history and how they still exert a strong influence on Indian cities. It is an important contribution to elaborate solutions that are more adequate to present problems and to develop new planning methodologies. Approaches that necessarily involve a more direct citizens' participation in decision making and in the implementation process. The suggestions he gives are consistent with Tomà Berlanda's approach about the necessity to de-colonise the education of architects and planners. As Menon says, this does not imply that a radically different (and possibly artificially constructed) 'Indian' approach should take their place, but rather than an insightful consideration of the positive and negative elements of each culture be carefully considered and evaluated.

The influence is in fact not only in the direction of Western to non-Western, but as it has been studied and described so many times, it also works in the opposite direction, even if less remarkably. Just think of Frantz Fanon's analysis of the complex interrelations between France and the French colonies (Fanon 1952, 1961), and the influence of the culture of some parts of Latin America on Spain and Portugal. The British in the 1800s wanted to anglicise the brains of the Indians (Macaulay 1835), but after two centuries India has in turn changed some aspects of British culture.

It is important to point out that this kind of interaction did not happen only at a particular moment, but it continues over time, with cultural systems that have changed. Think for instance of Kaiping's unusual Chinese architectural re-invention of European tradition. The cultural and political emergence of Asia is having (already it has had in visual art) a strong impact on the culture of the European and American West. This also applies to technology and science. See for example, the role that China has in Africa (once a backyard of Europe) which forces Europe to change traditional approaches to African social and economic issues. The newly created interests at social and economic level also apply to architecture and urban planning.

And think again for instance of the exportation of European and American architectural models to the oil-rich countries of the Persian Gulf; their local reinterpretation and adjustment to the specific requirements of that region; and their re-exportation from the Gulf to other countries all over the world. Only a few elements of the original models are kept; and new architectures have been originated. The same happens with the 100 smart-cities that the Indian government wants to build, and their inevitable alteration and re-invention to fit in local contexts. They will have little to do with the original South-Korean or American models, but at the same time, these adjustments will suggest to their prototypes changes and improvements. And finally, there is Shanghai's drive of transforming the image of the Western architecture of the beginning of last century into a local symbol, a nostalgic metaphor of a particularly important cultural moment. On the other hand, Shanghai is a mythical place for the West and has a strong impact on our imaginary. Both approaches suggest how relevant the discovery of traditional values and elements of another culture is.

As it has been said before, keeping the memory of their own past is a common element to many societies. But since the forms and contents of this process change over time and according to cultures and, the conservation of memory is an important key to understand cultural diversity, and how cultures contact each other, reciprocally contaminate and also conflict. Moreover, it represents the way in which each society considers itself and looks at the future. In a phase of great social, economic and political changes as the present one, such an indicator becomes important. 


\section{Heritage Conservation in an Increasingly Urbanised World}

In future years present trends of global urbanisation will become an issue of major concern. The fact that the whole world becomes urban will create a wide range of different situations and unexpected serious problems.

Some theories about what has been called the 'planetary city' (Brenner 2014, 2017; Robinson 2006; Roy and Aihwa 2011; Simone 2004) seem to assume that large-scale processes of urbanisation will possibly follow similar patterns and have similar outcomes. Others (Sassen 2002, 2014) suggest that the process of global urbanisation will be all but linear, and will possibly accentuate, instead of diminishing, elements of inequality, competition and conflict. While large-scale internal and international migrations will originate new widespread informal developments, already existing urban structures will focus on themselves to protect their established role and identity. Patchworked territories will emerge made of well-defined static elements and loose systems with strong dynamics and subject to continuous transformations. Such phenomena are intrinsic to globalisation. While an 'all-urban' condition suggests a free circulation of people, goods, information, and open spatial structures, this does not actually take place. Everything seems to look 'similar', but in fact, all components of the new spatial structure try to have an original identity, aim to self-protection. New urban developments show the coexistence of parts that do not intend to become similar. The more the scale of an economic, social and political system increases, the greater is the search for a specific identity and diversity of its components. In addition, there are geopolitical transformations that support the existence and legitimacy of different ways of being, behaving and thinking. Spatial structures that no longer can be ascribed to the traditional city with its historical components develop.

This process is already visible in several regions of the world, and in Europe in particular. Studies on Global South and research work on South Asian and African urban systems have already anticipated possible patterns of spatial organisation, different from the present ones. For this reason, it is important to understand the impact this process will also have on the conservation of heritage.

Both the papers by Giulio Verdini and Qing Chang examine the meaning and role that heritage and its preservation can have in a habitat generated by a sharp increase of population living in urban areas, and by the diffusion of an urban culture around the world. The progressive widening of the concept of heritage and its preservation that took place in the last century is strongly related to the transformation of the city and the territory that have simultaneously taken place. The shift of focus from the single monument to parts of cities and cultural landscapes takes place at the same time that cities 'explode' and larger portions of the territory are urbanised.

Giulio Verdini analyses in depth which are the principles and tools of heritage conservation appropriate to the present situation. The substantial transformations of urban systems originated by large migrations to cities and the fact that most of the world's population will be urban imply a redefinition of what cities are, the relations between their components, the relationship between urban areas and the remaining parts of the territory. The role and meaning of the historical parts of the cities, of the traditional landscapes, and of individual monuments will also considerably change. Once again this implies the necessity to revisit principles such as heritage, authenticity, conservation.

The immense slums that present social and economic processes are creating in all regions of the world are witnesses of our time and are culturally important as the precious buildings of famous architects. Could Kibera, the world's largest slum in Kenya (which is unique, authentic, integer) possibly be declared World Heritage in the future?

\section{Collective Action and Alternative Education}

So far we have examined a number of questions that arise when we look at the issues of heritage conservation in a world where different cultural systems (with different dynamics) coexist. Need for changing paradigms and methods has emerged. At this point, it is necessary to focus attention on another fundamental question: how can new conservation objectives be achieved and alternative policies implemented? The answer is on two levels: on the one hand, a different way of preserving the heritage, born from a direct and conscious participation of the entire population, and not only the professionals, should be put in practice; on the other hand, architects, planners, technical personnel, public managers should be trained differently.

The need to involve people more directly in the process of preserving their heritage is a consequence of the great urban transformations that are taking place. In a territory, people who belong to very different cultures and who interpret the conservation issue in very different ways come into contact with each other. They can cooperate in social and economic activities, but this does not mean that they also share the same cultural values. The challenge of a totally urbanised world is based on the assumption that 
different populations can live in the same new context while retaining their original identity. It is this possibility that makes the urban condition in the 'planetary city' one of freedom. It is then evident that both the new ways of living and the defence of cultural heritage are made possible thanks to the collective work of those who are directly involved in this process. In this sense, the Japanese experience of Machizukuri becomes an important point of reference. It is not only a more democratic and effective way of making cities and preserving their heritage but rather the only opportunity to express a shared culture. And this also makes possible a conservation practice that is aware of the future and anticipates it. The paper by Takashi Ariga is an important contribution to understand this issue better.

Equally important is the paper by Tomà Berlanda about the need to de-colonise the education of future civil servants and practitioners in regions of the world that have been under the colonial educational system for a long time (but his arguments can also be applied to countries that have either imported or copied their educational model from the West). A society willing to become free from models imported by the West that are inadequate to answer local needs, should start doing it in schools. Alternative principles, original work methods, different methodologies should be the basis for training new professionals. This different basic training is also necessary those who work in the field of conservation. Heritage conservation cannot be considered a specialised sector. A discipline without connections with the general principles of a new culture that relates architectural and urban design to the preservation of physical heritage (made of buildings, parts of cities, landscapes) and to a wider environmental context. As said before, the act of conserving is basically to design in different terms.

\section{Conclusions}

These considerations suggest that it is time to start a bold research process involving different actors: individuals, institutions, and cultural systems. Universities and research centres are supposed to play a key role in this process, that should focus on four main areas:

1. Elaboration of sound alternative theories and methods

Cultural systems that correctly claim that their specific approaches to heritage conservation are valuable and relevant should elaborate their theoretical basis and methodological approaches in a more systematic way. Too often we are confronted with important but fragmented contributions which do not offer an alternative to the Western theoretical and methodological body and are unable to raise a wide international debate. I am convinced that this is an important task for Chinese, Japanese and Indian universities and research centres. The seminal enterprise that Built Heritage has undertaken should be supported by seminars, research projects and publications.

2. Experimentation and assessment of alternative approaches

By using trial-and-error methods, the significance of alternative approaches to conservation should be assessed in reality. A very important research area would be the conservation of modern tangible heritage with its unprecedented dimension and complexity. This would give the possibility to evaluate advantages and limits of new solutions as those based on a stronger citizens involvement. It would also be important to monitor the outcomes of new conservation projects and their effectiveness. This is already taking place in Japan, with reference to Machizukuri and the diffusion of basic principles of satoyama and satoumi ecosystems. There are also similar experiences in China and India. I believe that universities-in cooperation with different governmental institutions-can effectively contribute to carry out experimental projects and assess their impact. Successful cases should be made better known and neweven small scale-experiments undertaken. Built Heritage can play an important role in this program.

3. Anticipation of new issues that conservation is facing and will have to face

Large-scale urbanisation processes that are taking place will create unexpected new situations and problems. Possibly new definitions of what should be in the future conserved, and for what reasons, will be necessary. In addition, the changing role of conservation in the present global economic and social context should be assessed. For instance, the relationship between heritage and tourism (the most important market force behind the present policies of heritage conservation and enhancement) in a communication society should be more carefully studied. They will strongly influence the future of conservation heritage. Contrary to what happened in the past, present heritage is conserved more for the economic advantages generated by tourism than for preserving the identity and values of a community. There is a deep gap between the cultural value we give to heritage and its commercial use. In addition, heritage sites that have become icons of the global market are inaccessible to most of the world population. They are replaced by virtual reality, mechanical reproduction and forgeries. These solutions are consistent with a communication-based society and they change the nature and meaning of heritage deeply. These are relevant issues that should be taken care of by universities in research 
projects, seminars, publications. Once again I think that Built Heritage can give important contributions on these matters.

4. Development of new educational methods

A final issue concerns the education of professionals who will be taking care of heritage conservation and the necessity of innovating contents and methods deeply in their training. I believe that to examine and discuss this issue an international conference of the leading architectural schools would be very useful and timely.

\section{References}

Augé, Marc. 2003. Le temps en ruines [Time in Ruins]. 2003. Paris: Editions Galilée.

Benjamin, Walter. 1969. "The Work of Art in the Age of Mechanical Reproduction.” In Illuminations, Hannah Arendt, ed. Translated by Harry Zohn. New York: Schocken Books.

Bernal, Martin, 1987. Black Athena: The Afroasiatic Roots of Classical Civilization. New Brunswick: Rutgers University Press.

Boardman, John. 2002. The Archaeology of Nostalgia: How the Greeks Recreated Their Mythical Past. London: Thames and Hudson.

Borofsky, Robert. 1987. Making History. Pukapukan and Anthropological Constructions of Knowledge. Cambridge: Cambridge University Press.

Brenner, Neil, ed. 2014. Implosions/Explosions. Towards a Study of Planetary Urbanization. Berlin: Jovis Verlag $\mathrm{GmbH}$.

Brenner Neil. 2017. Critique of Urbanization: Selected Essays. Basel: Birkhäuser Verlag.

Ceccarelli, Paolo. 2016. A Post-Western/Non-Western Approach to Urban and Architectural Issues. A Research Project Proposal. Ferrara: UNESCO Chair.

Chakrabarty, Dipesh. 2000. Provincializing Europe: Postcolonial Thought and Historical Difference. Princeton: Princeton University Press.

Comaroff, Jean, and John Comaroff. 2012. Theory from the South, or, How Euro-America Is Evolving toward Africa. Abingdon: Paradigm Press.

Connell, Raewyn. 2007. Southern Theory. The Global Dynamics of Knowledge in Social Sciences. Cambridge: Polity Press.

Crichton, Michael. 1999. Timeline. New York: Knopf.

Daly, Patrick, and Tim Winter. 2012. Routledge Handbook of Heritage in Asia. Abingdon: Routledge.

Edwards, Walter. 2003. "Monuments to an Unbroken Line: The Imperial Tombs and the Emergence of Modern
Japanese Nationalism." In The politics of Archaeology and Identity in a Global Context, edited by Susan Kane, 11-30. Boston: Archaeological Institute of America.

Enders, Siegfried R.C.T., and Niels Gutschow, eds. 1998. Hozon. Architectural and Urban Conservation in Japan. Stuttgart: Edition Axel Menges.

Fabian, Johannes. 2014. Time and the Other. How Anthropology Makes Its Objects. New York: Columbia University Press.

Fanon, Frantz. 1967. Black Skin, White Masks. Translated by Charles Lam Markmann. New York: Grove Press.

Fanon, Frantz. 1961. Les Damnés de la Terre. [The Wretched of the Earth] Paris: François Maspero.

Freud, Sigmund. 1985. The Complete Letters of Sigmund Freud to Wilhelm Fliess, 1887-1904. Translated and edited by Jeffrey Mousalleff Masson. Cambridge: Belknap Press.

Halbwachs, Maurice. 1950. La mémoire collective [The Collective Memory]. Paris: Presses Universitaire de France.

Hamilakis, Yannis. 2003. "Lives in Ruins: Antiquities and National Imagination in Modern Greece." In The Politics of Archaeology and Identity in a Global Context, edited by Kane, Susan, 51-78. Boston: Archaeological Institute of America

Handler, Richard. 1986. "Authenticity." Anthropology Today 2(1): 2-4.

Hobsbawm, Eric. 1983. The Invention of Tradition. Cambridge: Cambridge University Press.

Jedlowski, Paolo. 2017. Memorie del futuro. Un percorso tra sociologia e studi culturali [Memories of the Future. A Path between Sociology and Cultural Studies]. Roma: Carocci editore.

Jeudy, Henri-Pierre. 2008. La Machine patrimoniale [The Patrimonial Machine]. Paris: Circé.

Jokilehto, Jukka. 2006. "Considerations on Authenticity and Integrity in World Heritage Context." City \& Time 2(1): 1-16. URL: http//www.ct.ceci-br.org

Joyce, Rosemarie A. 2003. "Archaeology and Nation Building: A View from Central America." In The politics of Archaeology and Identity in a Global Context, edited by Susan Kane, 79-100. Boston: Archaeological Institute of America.

Jullien, François. 2015. De lêtre au vivre. Lexique euro-chinois de la pensée [From Being to Living. Euro-Chinese Lexicon of Thought]. Paris: Éditions Gallimard.

Kane, Susan, ed. 2003. The Politics of Archaeology and Identity in a Global Context. Boston: Archaeological Institute of America.

Kilani, Mondher. 1994. L'invention de l'autre. Essais sur les discours anthropologique [The Invention of the Other. Essays 
on Anthropological Discourses]. Lausanne: Payot.

Le Goff, Jacques. 1992. History and Memory. New York: Columbia University Press.

Liakos Antonis. 2002 “The Construction of National Time. The Making of the Modern Greek Historical Imagination." In Political Uses of the Past: The Recent Mediterranean Experience, edited by Jacques Revel and Giovanni Levi, 27-42. Frank Cass \& Co Ltd Publishers.

Lowenthal, David. 2008. "Authenticities Past and Present." CRM: The Journal of Heritage Stewardship 1(1).

Lowenthal, David. 1985. The Past is a Foreign Country. Cambridge: Cambridge University Press.

Macaulay, Thomas Babington. 1835. Minute on Indian Education. http://www.mssu.edu/projectsouthasia/history/ primarydocs/education/Macaulay001.htm

Meskell, Lynn. 1999. Remarks given in a paper at the AIA Annual Meeting, Dec., quoted by Susan Kane, Introduction to The Politics of Archaeology and Identity in a Global Context. Boston: Archaeological Institute of America.

Ministère de la Culture, Direction du Patrimoine. 1997. Actes des Entretiens du Patrimoine. Science et Conscience du Patrimoine (sous la direction de Pierre Nora). Paris: Fayard.

Ministère de la Culture, Direction du Patrimoine. 1998. Actes des Entretiens du Patrimoine. Patrimoine et Passions Identitaires (sous la direction de Pierre Nora). Paris: Fayard.

Morey, Sean and John Tinnell, eds. 2016. Augmented Reality: Innovative Perspectives Across Art, Industry and Academia. Anderson: Parlor Press.

Morris, Ian. 2000. Archaeology as Cultural History, Words and Things in Iron Age Greece. Malden: Oxford Blackwell.

Nehru, Lolita. 1989. Origins of the Gandhāran Style. A Study of Contributory Influences. Delhi: Oxford University Press.

Nora, Pierre. 1997. Realms of Memory: The Construction of the French Past: Traditions Vol. II. Translated by Arthur Goldhammer and edited by Lawrence Kritzman. New York: Columbia University Press.

Olivier, Laurent. 2008. Le sombre abîme du temps [The Dark Abyss of Time]. Mémoire et archéologie. Paris: Seuil.

Pingree, David E. 1978. The Yavanjātaka of Sphujidhvaja. Cambridge: Harvard Oriental Series, Harvard University Press.

Potter, Andrew. 2010. The Authenticity Hoax. New York: Harper Collins Publishers.

Poulot, Dominique.2006. Une Histoire du Patrimoine en Occident. XVIII-XXI Siècle. Du monument aux valeurs [A

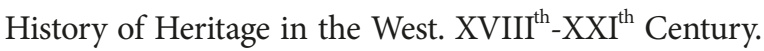
From Monument to Values]. Paris: Presses Universitaires de France.

Revel, Jacques, and Giovanni Levi, eds. 2002. Political Uses of the Past. The Recent Mediterranean Experience. London: Frank Cass \& Co Ltd Publishers.

Revel, Jacques, and Lynn Hunt. 1995. Histories: French Constructions of the Past. New York: The New Press.

Robinson, Jennifer. 2006. Ordinary Cities: Between Modernity and Development. Abingdon: Routledge.

Roy Ananya, and Aihwa Ong, eds. 2011. Wordling Cities: Asian Experiments and the Art of Being Global. Chichester: Wiley-Blackwell.

Rüsen, Jörn, ed. 2007. Time and History. The Variety of Cultures. New York: Berghahn Books.

Said, Edward. 1978. Orientalism. New York: Pantheon Books

Said, Edward. 1988. Nationalism, Colonialism, and Literature. Minneapolis: University of Minnesota Press.

Sassen, Saskia. 1991. The Global City: New York, London, Tokyo. Princeton: Princeton University Press.

Sassen, Saskia, ed. 2002. Global Network, Linked Cities. Abingdon: Routledge.

Sassen, Saskia. 2014. Expulsions. Brutality and Complexity in the Global Economy. Cambridge, Ma: Harvard University Press.

Simone AbdouMaliq. 2004. For the City yet to Come: Changing African Life in Four Cities. Durham \& London: Duke University Press.

Stovel, Herb. 2007. "Effective Use of Authenticity and Integrity as World Heritage Qualifying Conditions." City \& Time 2(3): 21-36. URL: http//www.ct.ceci-br.org

Todorov, Tzvetan. 2004. Les abus de la mémoire [Abuse of Memory]. Paris: arléa.

UNESCO, WHC. 1994. Nara Document on Authenticity. Phuket: WHC-94/CONF.003/INF.008

Wallerstein, Immanuel Maurice. 2006. European Universalism: The Rhetoric of Power. New York: the New Press.

Watertown, Emma, and Steve Watson, eds. 2011. Culture, Heritage and Representation. Perspectives on Visuality and the Past. Farnham: Ashgate Publishing Ltd.

Waterton, Emma, and Steve Watson. 2015. The Palgrave Handbook of Contemporary Heritage Research. Houndmills, Basingstoke: Palgrave Macmillan.

Winter, Tim. 2012. "Beyond Eurocentrism? Heritage conservation and the politics of difference." International Journal of Heritage Studies 20(2): 123-137.

Wu, Hung. 2012. A Story of Ruins, Presence and Absence in Chinese Art and Visual Culture. Princeton: Princeton University Press. 